\title{
Analysis of Financial Sector Reforms and Impacts: Reflections from Pakistan
}

\author{
Ali Raza, Muhammad Farhan, Muhammad Usman, Muhammad Akram* \\ Hailey College of Commerce, University of the Punjab, Lahore, Pakistan \\ *makram.hcc.pu.edu.pk@gmail.com
}

\begin{abstract}
The purpose of this paper is to examine all efforts made by the Government of Pakistan in order to uplift the efficiency of financial sector through financial restructuring institutions such as banks, as well as to recognize the impact of these reforms on various financial indicators. Results of this study suggested that financial sector performance was very much better after the completion of first generation reforms but many new reforms are still required for macroeconomic stability and economic growth of Pakistan. This was the first attempt made by researcher in which detailed discussion was provided about financial sector reforms and it will help out the policy makers while developing policies for future and it will enhance the knowledge of economists and all other beneficiaries as well. Moreover, discussion for further reforms and gap for future studies was also provided.
\end{abstract}

Keywords: Economic growth, Financial restructuring, Macroeconomic Stability, Reforms, Pakistan.

\section{Introduction}

An efficient financial system is required for establishment of investor friendly institutions, competitive financial markets in which investors can interact, and to facilitate economic transactions by reducing transaction cost and uncertainty. Ahmad et al. (2011) \& Alam et al. (2011) stated that an efficient financial system has proved a good facilitator for fund mobilization to institutions from investors and serving as a back-bone for the development of an economy. In the same manners, IMF (1996) reported that it has been observed that weak and inefficient financial system is always unable to cope with cash flow changes and exchange market pressures. Therefore, strengthened standards for banking supervision are required because effects of financial crisis are clearer due to inefficiency and weakness of financial system.

Hanif (2003) indicated that entities are the main component of financial sector which are engaged in transactions of foreign exchange, and capital and money markets' financial instruments, and many other sectors such as real, fiscal and external sector. Raza et al. (2011) also identified that financial institutions play a vital role in order to attain the efficient financial system and provide support to financial transactions.

From 1990s, it has been mostly observed in developing countries that certain measures have been taken to restructure the financial system and these measures include fiscal consolidation reforms of exchange rate, trade and deregulation of financial sector activities. In Pakistan, before restructuring the investment of private sector was modest, barriers to entry and oligopolistic practices were used to protect the financial intermediaries from domestic competition and tight restrictions were imposed on the transaction of capital and current accounts in order to keep them away from competition outside the country, and efforts were lacking for savings mobilization due to feeble competitive financial system (Khan, 1995). Therefore, like other developing countries, financial restructuring process was undertaken in Pakistan to remove all prior obstacles and limitations, to strengthen the role of market forces, increase in competition through liberalization of interest rate, and development of prudential supervision and reliable market information system in order to more efficiently deal with interest rate and other banking risks. This paper was purported to examine all efforts made by the government of Pakistan in order to get an efficient financial sector through financial restructuring as well as to recognize the impact of these reforms on various financial indicators.

\section{Review of Literature}

Literature of financial reforms dates back to the work of Gurley and Shaw (1955). Intellectual basis for financial reforms was provided by Shaw (1973) and McKinnon (1973).A comprehensive literature review 
on economic growth and financial development was provided by Levine (1997). Afterward, two studies were conducted in Pakistan named as: Hanif (2003), and Khan and Khan (2007). Mavrotos and Kelly (2001) and Eatswell (1996) illustrated that financial sector restructuring removes distortions that impedes free market condition. Shaw (1973) and McKinnon (1973) suggested that financial reforms play an important role in the processing of capital accumulation as a consequence of increase in savings and investment. In the same manner, Chowdhary (2000) judged that based on policy messages financial restructuring is demanded by both financial and real sectors for development and economic growth that frees up interest rates and eliminates the selective credit allocation. Now, it is considered by economists that inappropriate supervisory and regulatory policies not only enhance the financial crisis' likelihood but also retard long-term growth of economy. However, it is necessary to go through a process in order to undertake the financial restructuring. In addition, it is considered that financial restructuring process may have four phases: 1) Diagnosis the problem; 2) Damage Control; 3) Loss Allocation; and 4) Rebuilding Profitability. If the $1^{\text {st }}$ phase is correctly performed then institutions will be able to correctly grasp real problem or real cause of loss or extent of it, and it is performed by applying the uniform accounting and auditing standards. Second phase refers to stopping the flow of future losses either by liquidating or changing management. Third phase is linked with the proper allocation of loss incurred. Finally, rebuilding profitability refers to the making of good policies, strong institutional framework and efficient management.

Sheng (1996) defined the financial restructuring as "the package or macroeconomic, microeconomic, institutional and regulatory measures taken to restore problem are banking system to financial solvency and health". In this paper, banking sector problem is defined in terms of shortfall of credit requirement and non-performing loans (NPLs). Sheng said that "as a rule of thumb, banking distress is likely to become systemic when NPLs, net of provisions reached roughly $15 \%$ of the total loans". Narasimham Committee (1998) also defined it as" a weak bank should be one who's accumulated losses and net NPLs exceed its net worth or one who's operating profits less its income on recapitalization bonds is negative for three consecutive years". Practically, it is a complex process but it strengthens non-bank financial intermediaries and banks' balance sheet structure. Hoelscher (1998) reported that appropriate efforts are essential to repeal poor profitability and insolvency of institutions. Moreover, supervisory institutions and regulatory environment must be restructured and modernized. Sheng (1996) illustrated two types of restructuring: one includes the intervention of government; and other is based on the market for solution. In the same manners, Dziok and Pazarbasiougho (1988) recognized the two types of restructuring mechanism in order to restore the profitability and solvency of banks. First is known as financial restructuring and second is known as operating restructuring. Hence, financial restructuring can be undertaken to resolve the problem of bank solvency. But operational restructuring can be undertaken to resolve the problem of poor profitability because poor profitability is associated with the combination of high operating costs and non-performing loans. Caprio and Klingebil (1997) analyzed that bank insolvency was in result of mixture of bad banking and bad policies and argued that excessive expansion of credit was not only the cause of insolvency of institutions but poor policies were also one of the root causes. In addition, Khatkhate (1998) \& Alawade and Ikhide (1997) analyzed that speed of restructuring the measures is also very important for successful infrastructure.

It is a natural phenomenon that solutions are required when problems stated or near to occur. Same as financial reforms undertaken when crisis had occurred and many new were near to occur. Mishkin (1996) noted that "a non-linear disruption to financial markets in which adverse selection and moral hazard problems become much worse, so that the financial markets are unable to efficiently channel funds to economic agents who have the most productive investment opportunities". Moreover, four factors were determined that promote the financial crisis: 1) bank panics;2) increase in uncertainty;3) asset market effects on statement of financial position; and 4) increase in interest rates. Therefore, strong supervisory and regulatory system is required for the promotion of financial markets' efficient functioning and to cope with financial crisis. Barth et al. (1998) suggested the initial steps to reduce the financial crisis likelihood. Initial steps are: 1) Rate ceilings should be imposed on bank deposits; 2) Information disclosure and legal systems should be developed and improved; 3) Limits should be established on the rates at which bank expand the credit; 4) Greater diversification is required of the portfolios of banks; and 5) Restrictions should be reduced on the range of banking activities. 


\section{Financial Restructuring in Pakistan}

In the early 1990s, initiative of banking sector reforms was taken in Pakistan. Iimi (2004) stated that these reforms were undertaken with an objective to make financial industry transparent and competitive through liberalizing interest rates, standardized auditing and accounting systems, strengthening central bank's supervisory capacity, liberalizing credit ceilings, and privatization. All these reforms were undertaken after the advice of World Bank and IMF. Khan and Khan (2007) reported that "prior to the 1990s, the financial sector in Pakistan remained heavily controlled - All commercial banks were nationalized in January, 1974, with the aim at making credit availability to highly priority sectors of the economy which previously had limited access to investable funds. Interest rates were set administratively and were usually remained negative in real terms. Monetary policy was conducted primarily through direct allocation of credit. Money market was under-developed, and bond and equity markets were virtually nonexistent. Commercial banks often had to lend priority sectors with little concern for the borrowing firm's profitability. Despite the opening of non-bank financial sector for private investment in mid-1980s, state-owned financial institutions hold almost 93.8 percent of the total assets of the entire financial sector at the end of 1980s. Moreover, the status of financial institutions was precarious due to, inter alia, high intermediation costs resulting from overstaffing, large number of loss-incurring branches, poor governance with low quality banking services, accumulation of non-performing loans and inadequate market capitalization". To remove these inefficiencies and distortions, financial sector reforms were undertaken. These reforms were classified into three phases and recognized as first generation of reforms. The phases of financial sector reforms of first generation are:

First Phase of Financial Sector Reforms (1988-1996): This phase aimed at following five areas for reformation:

- Liberalization of policies regarding entry of the private banks and foreign banks;

- Privatization of Muslim Commercial Bank Limited (MCB) and Allied Bank Limited (ABL) during 1991 and 1993;

- Reduction in excessive number of employees of non-profitable branches of banks;

- Banking courts were established to improve the loan recovery process: and

- State Bank of Pakistan (SBP) was assigned full control over the financial sector.

Institutional Reforms: Several institutional inefficiencies resulted from nationalization of commercial banks in 1974 like credit allocation and decisions to recover loans were influenced by the political intervention. As a result, default loans were dramatically increased, profitability of the banks was deteriorated, and quality of services was dropped sharply. Therefore, SBP undertook numerous reforming steps to boost private sector participation like privatization of National Commercial Banks (NCBs) and empower them to constitute banks and non-banking financial institutions (NBFIs), and these reforms were undertaken to hike up competition and efficiency in financial sector.

Privatization: In 1990, Federal Government was empowered by making amendments in Banks (Nationalization) Act, 1974 to sell the share capital of NCBs wholly or partly. Later, in other reforms, it was bestowed to the government to set aside Banks (Nationalization) Act, where 26\% shares of the NCBs were disposed-off to the private sector. Moreover, the NCBs whose $51 \%$ of the shares have been sold to the private sector will not fall within the range of Banks (Nationalization) Act, 1974. Resultantly, MCB was privatized where $26 \%$ shares were sold in 1991 and by January 1993, control and management of the MCB was transferred to the private sector in addition to the disinvestment of further $49 \%$ shares of the bank. In September 1991, 26\% of the capital investment of the ABL was sold under Employee Stock Ownership Plan and Employee Management Group took over the control and management of the bank. Habib Credit \& Exchange Bank was denationalized and its management was transferred to the private sector in 1996.

Opening of New Banks and NBFIs: In 1991, private sector was encouraged to establish new banks by amending the Banks (Nationalization) Act, 1974, in order to hike up contention among financial institutions. In August 1991, resultantly 10 domestic private sector banks started operations namely: Bank Al-Habib Limited; Bolan Bank Limited; Askari Commercial Bank Limited; Republic Bank Limited; Union Bank Limited; Capital Bank Limited; Prime Commercial Bank Limited; Soneri Bank Limited; Indus Bank Limited; and Mehran Bank Limited. In 1994, Bank of Punjab and Bank of Khyber were adjudged as 
schedule banks. In 1995, a suspension was imposed in the formation of new banks to avoid growth of banks in Pakistan. However, the branch policy was eased for the growth of existing banks. In December 1996, the state owned banks were prohibited to open new branches.

\section{Institutional Strengthening}

Strengthening of Prudential Measures: The deterioration in credit discipline as well as quality of governance not only enticed the structural problems but also level of NPLs was worsened. These problems required prudential measures. In 1994, IDBP and NCBs required having capital adequacy ratio equivalent to $3 \%$ of time and demand liabilities that resulted in excessive lending by banks. In accordance with Basal Accord in FY96, the system of risk weighted capital was required to be adopted by all NCBs, NBFIs and foreign banks. Resultantly, capital plus general reserves of banks must be at least $8 \%$ of the minimum capital of the banks weighted by risk by the end of December 1997.

Strengthening of Loan Recovery Process: In February 1989, SBP issued guidelines to commercial banks to classify their loans and advances e.g. sub-standard debts, doubtful debts and loss. In November 1993, all commercial banks were directed to establish quarterly recovery goals, submit recovery reports, and formulate strategies for effective process of loan recovery. Simultaneously, minimum standards were introduced by SBP for the prospective borrowers to ensure that fresh loans will not be provided to the defaulters. For this purpose, SBP directed all the commercial banks to submit the defaulters list having balance Rs. 1 million and more.

Rectifying debt management: These reforms were designed with purport to shift the controlled rate of return to market based rate of return and to use the indirect monetary control instruments to implement monetary policy.

Auction System: In order to remove the negative impacts of tap system of managing debt, a paper was introduced by Dr. Ishrat Hussain and SBP sold Government of Pakistan Market Treasury Bills through an auction system successfully in April 1989. Resultantly, Securities Department was established in 1990 that launched auction system of government debt in addition to establishing government securities secondary market. In August 1992, a credit ceiling, which was relatively inflexible system, was replaced with relatively flexible system of fixing credit deposit ratio (CDR). However, in 1995, it was also repealed. At that moment scheduled banks were asked to extend credit through market based mechanism to the private sector.

Secondary Market Advancement: The advancement of secondary market was fairly dependent upon market making capabilities of the dealers, efficiency of payment system, and SBP privileges to dealers that enabled them to carry out their liabilities as well as to saving demeanor of people. Therefore, to attain the advancement of the secondary market some reforms were undertaken such as: invention of system of ADs; book based system for the settlement of government securities; denationalization; and encouraging the foreign investors.

Reforms in NSS: In 1989, KDCs dominated $71.6 \%$ share of unfold debts because of offering high returns. However, these were ceased in Feb. 1990 and three new instruments were introduced i.e. Special Savings Accounts; Special Savings Certificates; and Registered and Bearer certificate. Although these securities had lower returns, yet these were very attractive.

Monetary Management Measures: Before financial reforms, direct control was the instrument of monetary management. These include credit ceilings, direct interruption of government into the monetary policy, administratively determined interest rates etc. So, these weaknesses were required to be strictly addressed. Following measures were taken in this regard.

Monetary and Credit Management: On $9^{\text {th }}$ Feb. 1995, banks were required to maintain CDR of $1.5 \%$ of total time and demand liabilities. On $11^{\text {th }}$ December 1995, CDR was increased to $3.5 \%$ and ultimately in $1^{\text {st }}$ July 1996 it was abolished. In August 1992, CDR replaced credit ceilings and began to be used as credit control instrument. In January 1995, when CDR was repealed, open market operations were introduced that brought a dramatic change in monetary management that is now the key monetary measures instrument. From that time, SBP has been conducting open market operations (OMOs) using MRTBs as a 
main tool that assisted SBP to control inter-bank liquidity. In February 1992, 3-Day Repo facility of SBP replaced rediscounting facility. However, in May 1993, amendments were made in the procedure of getting this facility to avoid any misuse and banks were required to provide adequate justification to SBP to use it. In addition, SBP required all the banks to report repo transactions and inter-bank call money. On $9^{\text {th }}$ October 1991, SBP required all the banks to keep cash reserve ratio (CRR) plus 7\% of outstanding credit. This requirement was reduced in Jan. 15 $5^{\text {th }}$ 1992. Additionally, banks were required to maintain SLR, this ratio was declined to 35\% from 45\% in October 1993 and in March 1994 it was further reduced to $25 \%$. In 1998 , the ratio was determined as $15 \%$.

Banking Law Reforms: During 1990s, several reforms were made in banking laws. These reforms were undertaken to facilitate privatization process, opening new banks, increasing competition, enhancing authority of SBP for the formulation and implementation of monetary policy, to improve the corporate governance and to improve the loan recovery process. These reforms were: 1) government was vested with the authority to establish private sector bank for the promotion in 1991; 2)certain amendments were made in the Act in 1994 to enhance the authority of the SBP regarding governing monetary system as well as credit system and Monetary and Fiscal Policies Coordination Board was established; 3) banking Company Ordinance was also amended that empowered SBP to determine CRR and SLR for banks; 4) in February 1994, amendments were made in SBP Act, and Board of Directors (BOD) of banks were equipped with the authority over the administration and control of the business; and 5) Section 40(A) was inserted in Banking Company Ordinance and authorizing the SBP to monitor the performance of banks.

Exchange and Payment Reforms During 1990s: These reforms were started in 1991 with an intention to create to a favorable environment not only for domestic investment but also for foreign investment. However: 1) in 1996, for the purpose of increasing the efficiency of payment system and replacing the manual system with computer based system named as national institutional facilitation technology (NIFT) was established; 2) with regard to export, no prior approval was required for the organizations to obtain foreign exchange that participate in international trade exhibitions; 3 ) with regard to import, the condition to acquire import license was removed; and 4) importers that were registered with EPB were allowed to import not exceeding US\$10,000 without getting performa invoice registered with ADs or through opening the letter of credit (LC).

Second Phase of Financial Sector Reforms (1997-2001): Second phase was started in early 1997 with reforms that were initiated to save the economy from being collapsed. In 1996, the financial sector was caught with NPLs and liquidity problems due to increase in losses of banks. That was triggered due to lack of governance, political interference and loan defaults particularly of NCBs and Development Finance Institutions (DFIs) whose above $90 \%$ of loans were defaulted. However, these reforms were concerned about the followings:

- Restructuring the banks through improving capital adequacy;

- Commercial banks that were partially privatized in the first phase were completely privatized;

- Private Banks were allowed to enhance market share and their branches were liberalized;

- Conditions regarding loans' collateral were modified to target lower income people and to reduce the risk of default;

- Necessary reforms were made in NSS;

- Minimum deposit requirements in FCAs were abolished; and

- Enhancing the regulatory authority of SBP for the banking sector while elimination of credit program at concessional rates.

Restructuring of Banks and DFIs: Since, NCBs have been increasing their branches to remote areas of the countries but their efficiency has been declining and workforce has been over employed. These counter-balanced the initial advantages of nationalization. Particularly, the increase in transportation cost resulted increase in lending rates and decrease in return on deposits. In September, 1997 two privatized banks, two specialized banks and three nationalized banks introduced several schemes, with the intention to downsize the employee through the scheme of golden shake hand. With this scheme, the number of employees reduced to 81,079 by the end of December 1999 from 99,954. In branch closure 
scheme, banks were allowed to close the unprofitable branches purely for commercial considerations. Therefore, the numbers of branches were reduced to 7,955 by June 2000 from 8,673 in June 1997.

\section{Institutional Reforms}

Strengthening of Prudential Measures: In 1996, a significant portion of assets of banks was stuck up as NPLs. To arrest such problems, Financial Institutions (Recovery of Finance) ordinance 2001was promulgated. Additionally, National accountability Bureau (NAB) Ordinance 1999 was promulgated that regarded willful defaults as corruption. As a supplementary to the loan recovery process, an asset management agency named as Corporate and Industrial Restructuring Corporation (CIRC) was established that assumed NPLs more than Rs 10 million of all private sectors.

Strengthening of Loan Recovery Process, Disclosure Standards for Banking tribunals: In august 1997, the disclosure standards for banks were revised by SBP, shifting the traditional accounts formats to the new formats that met the requirements of international accounting practices. In 1993, banking tribunals for non-interest bearing loans were increased to 11 from 3 and for interest bearing loans to 14 . In December 1996, new project loans of NCBs were restricted by government till June 1997. In June 1997, SBP introduced three-tined loan recovery mechanism that includes: 1) A pardon scheme for encouraging the defaulters to satisfy their loans; 2) Those defaulters, who failed to avail the said scheme by $5^{\text {th }}$ September 1997, will be presented before the new banking courts; and 3) New management to be appointed and asset recovery departments to be strengthen of NCBs and DFIs. Resultantly, by $15^{\text {th }}$ November 1998, Rs 34.7 billion was recovered from total defaults. In October 1999, a deadline for one month was issued to the defaulters to satisfy their outstanding amount by the government. Thereby, Rs 13.5 billion were collected during three month period from October to December 1999. Moreover, it was necessitated for all commercial banks to get credit rating services of an approved rating agency in June 2000.

Institutional Strengthening of SBP: In 1997, certain amendments were made in the said Act to further enhance the responsibilities of SBP. Systems of CAMELS (See BPRD circular No. 36, dated November 4, 1997) were introduced under which banks and NBFIs evaluated their performance. In FY 2000, the Securities Department and the Foreign Exchange Dealing Room were merged to established Exchange and Debt Management Department to coordinate the operations of the securities that were in Pak rupee denomination and that were in foreign exchange that resulted in the free float of the PKR in 2001.In 1999-00, central and non-core functions of SBP were separated. Subsequently, SBP was divided into two parts: SBP; and Banking Services Corporation (Bank). The former was responsible for the formulation of monetary policy and financial sector regulations, management of foreign exchange and payment system. The later was liable for treasury functions and retail banking. On January 21 1997, SBP Act 1956, BCO 1962 and Banks Nationalization Act, 1974 were amended. Thereby further enhancing the authority of SBP. With reference to new rules (a) SBP was authorized to develop credit policy in consistent with macroeconomic targets. Banks regulated by SBP cannot be subject to issuance of directives by government. These amendments dissolved Pakistan Banking council (PBC) and SBP become the sole entity to regulate the financial sector. Moreover, in order to ensure efficient payment system, in 5 June 2000, SBP required all the banks to have membership of NIFT.

Promotion of Secondary Market: In 2000, criteria were formulated for the PDs. The financial institutions that have deposit with SBP were declared as Approved Dealers and the financial institutions that did not had an account with SBP were required to communicate a letter to SBP from their banks that for the purpose of settlement of accepted bid that would allow SBP to take off the required amount from the balance. This system gain through in developing primary market of government securities i.e. T-bills and FIBs.

Banking Law Reforms: In January 1997, government bodies were prohibited to issue guiding to the banks or any other financial institution under the regulation of the SBP through the inserting a new section in SBP Act 1956. Furthermore, Central Board was given in charge for the formulation of monetary policy and credit policy in accordance with the objectives put forth by Monetary and Fiscal Policies Coordination Board of macroeconomic stability. Furthermore, Central Board was given responsibility to determine credit limits of SBP for governments and their agencies, submit a report on the economic 
condition to the Parliament on quarterly basis, approve private sector credit requirements and give suggestions on economic policies to the federal government.

Banking Companies (Recovery of Loans, Advances, Credits and Finances) Act, 1997: Banking Companies (Recovery of Loans, Advances, Credits and Finances) Act, 1997 was enforced to re-enact the Banking Tribunal Ordinance 1984, and Banking Companies (Recovery of Loans) ordinance, 1979. These hasten the loan recovery process thorough the establishment of the banking courts.

\section{Monetary Management Measures}

Promoting Intermediation: FCAs were introduced to take in funds held by Pakistanis' in abroad. These accounts could be opened by Pakistani resident with banks situated in Pakistan. This account could be opened without any enquiry of the source of funds. Moreover, this account was not chargeable to income tax and wealth tax. The holder of such account could obtain loan even in Pakistani Rupee.

Encouraging Foreign Investment: For the purpose of encouraging foreign investment in Pakistan, investors were allowed to invest in all industries without any prior approval of SBP even up to $100 \%$ equity on repairable basis. Investment in corporate debt instruments by foreign banks operating in Pakistan including investment banks controlled by foreign government and non-residents was allowed either through public offerings or secondary markets. Moreover, non-residents were permitted to trade in quoted shares through opening the Special Convertible Rupee Account (SCRA). Finally, private sector in Pakistan was allowed to borrow from abroad with certain conditions. In 1999, Section 23 of SBP Act, 1956 was amended that empowered SBP to freely buy and sell foreign currency.

Liberalizing Forex Market: In February 1998,Authorized Dealers(Ads) were allowed to determine the exchange rates on the basis of demand and supply forces other than the determination of exchange rate with US dollar that continued by SBP.

Discouraging Capital Outflows: The influential powers of the ADs were withdrawn for discouraging capital outflow from the country. The power of the ADs to release foreign exchange for travelling purposes was also withdrawn. However, most of these prohibitions were removed as economy regains its momentum.

Capital Market Reforms: In 1997, government of Pakistan collaborated with Asian Development Bank (ADB) and established Capital Market Development Programmed (CMDP) for: increasing competition; fortifying governance; modernize infrastructure of market; improving mutual funds; and establishing leasing industry etc.

Creation of SECP: For the purpose of improving governance and regulation of securities market, in December 1997, SECP was established replacing Corporate Law Authority (CLA) through Act No. XLII of 1997. After the establishment of SECP, it proactively contributed to streamline capital market activities. In 1993, CDC was formulated for the facilitation of electronic transfer of money. However, it was started functioning in September, 1997. Credit for the establishment of CDC goes to stock exchange in co-actions with Citibank, DFIs, IFC, and leading commercial banks. The transparency of market was considerably increased with the establishment of PACRA in 1994 and DCR-VIS Credit Rating Co. Ltd. in 1997. Moreover, three stock exchanges were automated and their rules and regulations were revised that helped to boost the investors' confidence thus increasing trade activities.

\section{Others Reforms}

Freeze of FCAs: For the purpose of impeding large forex liability, the holders of FCAs were prohibited to withdraw hard currency from their FCAs. NBFIs investment certificates, and encashment of FEBCs, FCBCs, and DBCs was restricted. However, the holders could withdraw money by converting foreign currency into Rupee at current exchange rate. To encourage the conversion of foreign currencies into Rupee, the exemptions provided on FCAs regarding tax and deduction of zakat were withdrawn. Special US Dollar Bonds were also offered to FCA holders. Later, minimum maturity of these bonds was reduced from 5 to 3 years and maximum return was increased from LIBOR +2 to LIBOR +4 . However, in June 1999 directions were issued to the banks and NBFIs to keep FCAs deposits within Pakistan. 
Introduction of Multiple Exchange Rate Regimes: In July 1998, a mechanism was initiated in exchange rate regime. It consisted of official exchange rate that was determined by SBP and FIBR i.e. floating interbank exchange rate that was determined by interbank market. These two rates were used in all transactions excluding certain categories. In December 1998, the share of FIBR was increased to $80 \%$ from 50\% and in March 1999 from 1995. Finally, in 19th May 1999, FIBR was adopted and it began to use in all foreign exchange dealings. SBP removed the restrictions on approved dealers to deliver foreign exchange or receipts of it. In May 1999, an unofficial cap was imposed on Rupee trading in the inter-bank market. It was removed on $21^{\text {st }}$ July 2000 after about one year when Rupee have been completely floated that was a chief achievement in exchange rate management.

\section{Third phase (2002-2004)}

Minimum Capital Requirement and Privatization: For the purpose of increasing the financial strength of the banking sector and to eliminate the weak entities SBP raised minimum capital requirement from Rs. 1 billion in 2003 to Rs. 2 billion in 2005. Resultantly, 17 mergers and acquisitions took place during this period and supervision of NBFIs was shifted to SECP in 2002. Moreover, Liberalization process that was started in first phase completed in third phase. UBL was privatized on May 2002. HBL was denationalized in 2003 that was taken over by AKFED. Although its privatization was started in 1997 but it was suspended later when Mr. Shaukat Tareen was appointed as a president of the bank. All stateowned commercial banks were privatized. Consequently, 100\% denomination of the government in the commercial banks in 1991 reduced to mere $20 \%$ in 2004.

Automation, PRs and KYC: The reforms along with their objectives were: 1) in order to promote ecommerce, all the scheduled banks were directed to connect to ATM switches by $3^{1 s t}$ December 2002; 2) SBP relaxed debt to equity ratio to 80:20 to boost private sector investment in selected projects of infrastructure sector including road, telecommunication, power generation and distribution, refinery project, pipeline project etc.; 3 ) in order to increase the efficiency of reporting to CIB and receipt of credit report from CIB, SBP collaborated with PBA and online CIB; and 4) SBP issued the following guidelines to avoid money laundering and white collar crimes through banking sector:

- True identity of all customers shall be ascertained by the banks performing all possible efforts;

- Introduction of each prospective customer shall be obtained at the time of opening new account to access integrity and nature of business;

- Due diligence process shall be on going for achieving careful banking; and

- Each bank shall design its own KYC approved by board of directors of the concerned bank.

Banking Audit, Supervision and Corporate Governance: For the purpose of improving guidance and supervision of bank, SBP starting using CAMELL and IRAF that measures the risk of the bank for improving the corporate governance and corporate governance code 2001 was introduced by SBP and SECP. Reforms included: 1) format of financial statements brought in line with international standard that was necessary for ensuring the transparency of the financial statements of the bank; 2) for the promotion of good governance, banks were required to get approval from SBP for the appointment of executives after following Fit and Proper Test formulated by SBP that ensures honesty, financial integrity etc.; 3) SBP issued the guidelines to the BOD of banks for regularly review the policies of internal management, MIS, credit disbursement etc. to ensure the effective governance; 4) SBP put cap of Rs 10,000 on Rupee Travelers' cheques that were necessary for discouraging fostering of undocumented transactions; and 5) due to the continuous increase in the level of NPLs, SBP and SECP established a committee for CRSIU and CIRC but the committee was failed then SBP made a scheme under which the borrowers were required to pay $10 \%$ down payment and balance in 12 quarterly installments.

Relaxation in Tax Liabilities for the Banking Sector: Pakistani banks have been facing the problem of high tax rate and withholding tax. In 2001, corporate tax rate was reduced to $50 \%$ from $58 \%$. Again, in 2003 it was reduced to $47 \%$. Additionally, withholding tax associated with treasury bills was also reduced. These measures were undertaken so that banks reduce the difference between deposit rates and lending rates. 
Policies for Promotion of Islamic Banking [Circular Letter BPD-1 (1 January, 2003)]: For the purpose of promoting Islamic banking in Pakistan, SBP formulated a three-pronged strategy: 1) allowing private sector to establish Islamic banks; 2) allowing the existing commercial banks to establish subsidiaries; 3 ) allowing the existing banks to establish independent branches; and 4) SBP also issued guidelines for achieving above mentioned objectives.

Micro Finance Banks [Circular Letter BPD-10 (17 November, 2003)]: Micro finance banks were obligated to rate by a registered credit rating agency. Moreover, some guidelines were issued by the SBP for mobile banking based on BSD-2 issued on 14 February, 2003: 1) license authorizing to operate branch will be deemed to be licensed to operate mobile banking but not more than 50KMs far from such licensed branch; 2) banks were needed to ensure standardization while rendering mobile banking services and needed to prepare Bank-wide Mobile Banking Strategy. The copy of such strategy shall be presented to SBP and shall be reviewed by the bank semi-annually; 3) while opening an account, the client must be identified in accordance with PRs of MFIs/MFBs; 4) statement of accounts shall be provided to the client at regular intervals; 5) all the cash received on account of mobile banking shall be deposited with the branch by evening on daily basis; and 6) branch manager shall review all the transactions pertaining to mobile banking.

Foreign Exchange: Foreign exchange manual (Eighth Edition-2002) was amended and certain additions were also made for the liberalization of foreign exchange regime such as: 1 ) incoterms 2000 will be adopted which were introduced by ICC; 2) limit of holing export proceeds in SFCA increased by $10 \%$; 3 ) imports limit of USD 5,000 was abolished in case of end users; and 4) imports limit of USD 30,000 has been abolished.

\section{Establishment of Subsidiaries and Supervision}

Banks / DFIs [BSD-2 (14 January, 2004)]: SBP made it compulsory for all banks and DFIs to promptly inform any essential changes and any adverse development. The compliance of these instructions shall be inspected by banking Inspection Department in its regular inspection. SBP increased his interaction with management, board of directors and external auditor. SBP also hold meeting s with higher management at least once in a year.

Establishment of Subsidiaries by Banks / DFIs [BPD-08 (8 March, 2004)]; In order to facilitate banks and DFIs to diversify their products through the establishment of subsidiaries, SBP issued the following measures such as: 1) subsidiaries shall be established after the approval of SBP; 2) subsidiary shall be incorporated as public company; 3) BOD of the subsidiary shall not be dependent to that of bank / DFI; 4) Bank/DFI shall increase the investment in subsidiary after the approval of SBP; and 5) strengthening the rural banking, consumer financing, housing finance, SMEs and micro financing.

\section{Impact of Financial Sector Reforms}

Interest Rate Policy: Economic activities and business conditions are directly affected by the interest rate. Before 1990, the real interest rates ware normally negative and set administratively. For example, savings were discouraged because negative real deposit rates were paid. Ceilings were imposed on interest rate in order to encourage investment but banks were providing the loans particularly in priority sectors. Resultantly, alternative outside outlets were become the preferable for investors and savers. After liberalization, easy monetary policy was presented by the government of Pakistan during the period of July 1995-2000. This step was taken only to encourage the credit expansion to private sector and to reduce the domestic debt cost of borrowing of government. Therefore, the price of financial services was started to determine by commercial banks on the base of competition along with the intervention of State Bank of Pakistan. 
Table 1 : Behavior of Interest Rate in Pakistan

\begin{tabular}{cccccccc}
\hline Years & $\begin{array}{c}\text { Inflation } \\
\text { Rate }\end{array}$ & \multicolumn{2}{c}{$\begin{array}{c}\text { Weighted Average } \\
\text { Lending Rate }\end{array}$} & \multicolumn{2}{c}{$\begin{array}{c}\text { Weighted Average } \\
\text { Deposit Rate }\end{array}$} & \multicolumn{2}{c}{$\begin{array}{c}\text { Interest Rate } \\
\text { Spread[Lending Rate- } \\
\text { Deposit Rate] } \\
\text { Nominal }\end{array}$} \\
& & Real & Nominal & Real & Nominal & Real \\
\hline $1990-$ & $10.57 \%$ & $12.55 \%$ & $1.98 \%$ & $6.53 \%$ & $-4.05 \%$ & $6.02 \%$ & $5.95 \%$ \\
1995 & & & & & & & \\
1996 & 10.8 & 14.40 & 3.60 & 6.40 & -4.40 & 8.00 & 8.00 \\
1997 & 11.8 & 14.60 & 2.80 & 6.80 & -5.00 & 7.80 & 7.80 \\
1998 & 7.80 & 15.60 & 7.80 & 6.80 & -1.00 & 8.80 & 8.80 \\
1999 & 5.70 & 14.80 & 9.10 & 6.50 & 0.80 & 8.30 & 8.30 \\
2000 & 3.60 & 13.52 & 10.9 & 5.47 & 1.90 & 8.05 & 9.00 \\
2001 & 4.40 & 13.61 & 9.21 & 5.27 & 0.87 & 8.34 & 8.34 \\
2002 & 3.50 & 13.19 & 9.69 & 3.61 & 0.11 & 9.58 & 9.58 \\
2003 & 3.10 & 9.40 & 6.30 & 1.61 & -1.49 & 7.79 & 7.79 \\
2004 & 4.60 & 7.28 & 2.68 & 0.95 & -3.65 & 6.33 & 6.33 \\
2005 & 9.30 & 8.81 & -0.49 & 1.37 & -7.93 & 7.44 & 7.44 \\
\hline
\end{tabular}

Source: Khan and Khan (2007)

Table 1 is clearly demonstrating the gradually decline in weighted average lending rate from 15.6 in 1998 to 8.81 in June 2005. Subsequently, real interest rate has an increasing trend from $3.6 \%$ in 1996 to $10.9 \%$ in 2000 along with the decreasing trend and in June 2005 it reached to $-0.49 \%$ and this reduction indicates a little improvement in banks' profitability but purely ad-hoc. Similarly, weighted average deposit rate has declining trend from 6.8\% in 1998 to 1.37\%2005 but except for period 1999-2002, real deposit rate remained negative. Resultantly, savings will reduce even further.

Khan (2003) \& Khan and Khan (2007) reported that "the interest rate spread is an important indicator for the financial sector's competitiveness, profitability and efficiency. Spread typically declined when competition among banks increases to access the financial market to increase their customer's base. The high lending rate will increase the cost of borrowing and hence discourage investment. The low deposit rates discourage both consumption and savings, resulting high debt/GDP ratio, deterioration of banks' balance sheet, lowering economic growth, and increase in poverty. Furthermore, the large spread also reflects perceived sovereign risk". But in Pakistan, the large spread was generated through low deposit rate and high lending rate which was $6.33 \%$ in 2004 and $7.44 \%$ in June 2005 . In order to enhance investment and saving, interest rate spread must and this scenario led to new reforms.

Performance and Efficiency of Financial Institutions: Khan and Khan (2007) explained that financial institutions' performance and efficiency is associated with solvency and profitability. Measures of solvency affect the statement of financial position while comprehensive income of institutions is affected by the profitability measures. Moreover it is considered that NPLs is a good measure in order to measure the financial institutions' profitability.

Table 2 : Behavior of Non-performing Loans of Banking System

\begin{tabular}{|c|c|c|c|c|c|}
\hline Year & NPLs (Billion) & $\begin{array}{l}\text { Gross NPLS } \\
\text { Advances }\end{array}$ & to & Provisions to NPLs & $\begin{array}{c}\text { Net NPL to Net } \\
\text { Advances }\end{array}$ \\
\hline 1997 & 173.00 & $23.50 \%$ & & $46.60 \%$ & --------- \\
\hline 1998 & 183.00 & 23.10 & & 58.60 & $11.10 \%$ \\
\hline 1999 & 230.70 & 25.90 & & 48.60 & 15.30 \\
\hline 2000 & 240.10 & 23.50 & & 55.00 & 12.20 \\
\hline 2001 & 244.10 & 23.40 & & 54.70 & 12.10 \\
\hline 2002 & 231.50 & 21.80 & & 60.60 & 9.90 \\
\hline 2003 & 222.20 & 17.00 & & 63.90 & 6.90 \\
\hline 2004 & 211.20 & 11.60 & & 70.40 & 3.80 \\
\hline 2005 & 177.30 & 8.30 & & 76.70 & 2.10 \\
\hline
\end{tabular}

Source: Khan and Khan (2007)

The problem of NPLs was considered as a big problem for the DFIs and NCBs in Pakistan. But after the reforms the situation was changing. Table 2 is depicting the entire summary very clearly. The NPLs were increasing from 1990 to 2001 but after it NPLs were decreasing. As a result, gross NPLs to advances ratio 
was declining in all years except 1999. The ratio of provisions to NPLs was also increasing in all the years except 1999 and 2001. The last ratio - net NPL to net advances - was also declining and reached to $2.10 \%$. All the results were in the favor on financial institutions and showed that many efforts were undertaken by the government of Pakistan in order to increase the efficiency of financial institutions. But more reforms are required because $100 \%$ results are not attained yet.

Profitability and Financial Soundness: Profitability and financial soundness of the financial institutions can be measured through the financial ratios. In this study some ratios were taken as proxy of profitability and financial soundness of financial institutions.

Table 3 : Earnings and Profitability of Banking Sector

\begin{tabular}{llllll}
\hline Proxy of Earnings and Profitability & $\mathbf{1 9 9 9}$ & $\mathbf{2 0 0 0}$ & $\mathbf{2 0 0 1}$ & $\mathbf{2 0 0 2}$ & $\mathbf{2 0 0 3}$ \\
\hline Return on Assets after Tax (ROA) & -0.20 & -0.20 & -0.50 & 0.10 & 1.00 \\
Return on Equity after Tax (ROE) & -6.20 & -0.30 & -0.30 & 13.80 & 22.10 \\
Net Interest Income to Gross Income & 54.30 & 61.20 & 68.90 & 67.40 & 58.20 \\
Non-Interest Expenses to Gross Income & 76.90 & 71.60 & 62.70 & 57.30 & 50.40 \\
Personnel Expenses to Non-Interest Expenses & 57.00 & 54.30 & 52.60 & 51.40 & 50.10 \\
Non-Interest Income to Total Income & 17.60 & 16.50 & 14.50 & 18.10 & 30.90 \\
\hline
\end{tabular}

Source: Khan and Khan (2007)

Table 3 is showing the earnings and profitability of banking sector. ROA and ROE ratios were positive in 2002-03 while ROE ratio was better and sustain in 2000-01 from 1999. Net interest income to gross income ratio was increased in1999-01 then it reduced in 2002-03 due to the retrenchment of interest margin and reached at $58.20 \%$ in 2003. Akhtar (2007) pointed-out that "the profits of commercial banks crossed over $\$ 1$ billion for the first three quarters of 2006. She further noted that from 2000-2006, the returns on assets of banks rose from $-0.2 \%$ to $2.1 \%$ and return on equity from $-3.5 \%$ to $26.1 \%$. This increase in profit may be attributed to many factors such as: (i) a rise in earning assets of commercial banks to $85 \%$ in September 2006 which is significantly above the pre-reform period and a rise in advances to total assets from $49.1 \%$ in 2000 to $55.1 \%$ in September 2006, (ii) a decline in the total and operating expenses to income, (iii) a rise in the SME, consumer finance and agriculture sector lending which constitutes over one third of total outstanding advances, (iv) a high share of non-interest bearing deposits and declined share of fixed deposits, and (v) a growth of service charges by the use of electronic banking". Additionally, it can be contended that privatization has had distinct impact on banking sectors' profitability; conversely its sway on efficiency is weak.

\section{Conclusion}

The important dimension of this study is the theoretical contribution and it fills important gap in relevant literature. This study is purported to examine all efforts made by the Government of Pakistan in order to get an efficient financial sector through financial restructuring of financial institutions such as banks, as well as to recognize the impact of these reforms on various financial indicators because financial restructuring was not an event but it is a continuous process. The condition of Pakistan financial sector was very weak before 1990 regarding the areas of corporate and banking governance, market discipline, legal infrastructure, prudential regulations, and accounting standards. As a result, financial institutions exposure increased to various external threats such as increase in NPLs of banking sector, reversal of capital flows, exchange rate devaluation, speculative attacks, market contagion, and decline in asset values. However, numbers of reforms were undertaken in Pakistan in order to resolve these problems from 1990 to 2004.In response to the reforms, operational efficiency and financial discipline showed a significant improvement. Moreover, the landscape of Pakistan dramatically has changed by the privatization.

It is suggested that capital market development is needed to be addressed properly. Legal infrastructure must be established for foreclosure, bankruptcy, and financial supervision. Prompt corrective and early warning system are needed. In order to maintain confidence, deposit insurance scheme is needed, and enhancement in transparency laws relating to bank secrecy is required. This is the first attempt in which detailed discussion is provided about reforms and it will help out the policy makers to develop the further policies and to enhance the knowledge of economists and all other beneficiaries as well. The researcher was unable to judge the impact of reforms of first generation in detail along with the identification of 
reforms of second generation. Practical contribution in literature and identification of areas which need further reforms tend to further study.

\section{References}

Ahmad, H. K., Raza, A., Amjad, W. \& Akram, M. (2011). Financial Performance of Non-Banking Finance Companies in Pakistan. Interdisciplinary Journal of Contemporary Research in Business, 2(12), 732-744.

Akhtar, S. (2007). Pakistan Banking Sector The Need for Second Tier of Reforms. Bank of International Settlement Review, 5, 1-6.

Alam, H., M., Raza, A. \& Akram, M. (2011). A Financial Performance Comparison of Public vs. Private Banks: The Case of Commercial Banking Sector of Pakistan. International Journal of Business and Social Science, 2(11), 56-64.

Alam, H. M., Raza, A. \& Akram, M. (2011). Financial Performance of Leasing Sector: The Case of Pakistan. Interdisciplinary Journal of Contemporary Research in Business, 2(12), 339-345.

Alam, H., M., Raza, A., Farhan, M. \& Akram, M. (2011). Leasing Industry in Pakistan: A Comparison of Financial Performance of Leasing Companies. International Journal of Business and Social Science, 2(10), 218-223.

Barth, R., Alan. R. \& Chorng-Huey, W. (1998). IMF Institute (Washinton: International Monetary Fund).

Caprio, J. G. \& Klingebiel, D. (1996). Bank Insolvency: Bad Luck, Bad Policy or Bad Banking? Annual Conference on Development Economics, The World Bank.

Chowdhury, A. (2000). Politics, Society and Financial Sector Reform in Bangladesh. WIDER Working Paper 191, the United Nations University.

Dziobek, C. \& Pazarbasioglu, C. (1998). Lesson from Systemic Bank Restructuring: Experience of 24 Countries. IMF Survey.

Eastwell, J. (1996). International Capital Liberalization: The record. CEPA Working Paper Series 1, University of Cambridge.

Gurley, J. G. \& Shaw, E. S. (1955). Financial Aspects of Development and Growth. American Economic Review, 45, 515-38.

Hanif, N. M. (2003). Restructuring of Financial Sector in Pakistan. The Journal of the Institute of Bankers in Pakistan, Jan, 1-29.

Hoelscher, D. S. (1998). Banking System Restructuring in Kazakhstan. IMF Working Paper 96 (Washington: International Monetary Fund).

Iimi, A. (2004). Banking Sector Reforms in Pakistan: Economies of Scale and Scope, and Cost Complementarities. Journal of Asian Economics, 15, 507-528.

IMF. (1995). Benefits of Capital Hows Tied to Strong Risk Management. IMF Survey (Washington).

Khan, A. H. (1995). Need and Scope for Further Reforms in the Financial Sector in Pakistan. Journal of the Institute of Bankers in Pakistan.

Khan, M. A. \& Khan, S. (2007). Financial Sector Restructuring in Pakistan. MPRA Working Paper 4141, Retrieved from http://mpra.ub.uni-muenchen.de/4141/

Khatkhate, D. (1998). Timing and Sequencing of Financial Sector Reforms: Evidence and Rationale. Economic and Political Weekly.

Levine, R. (1997). Financial Development and Economic Growth: Views and Agenda. Journal of Economic Literature, 35(2), 688-726.

Mavrotas, G. \& Kelly, R. (2001). Saving Mobilization and Financial Sector Development: The Nexus. Saving and Development, 25(1), 33-66.

McKinnon, R. I. (1973). Money and Capital in Economic Development. Washington (D.C): Brookings Institution.

Mishkin, F. S. (1996). Understanding Financial Crisis: A Developing Country Perspective. Annual Conference on Development Economics, the World Bank.

Raza, A. Farhan, M. \& Akram, M. (2011). A Comparison of Financial Performance in Investment Banking Sector in Pakistan. International Journal of Business and Social Science, 2(9), 72-81.

Shaw, E. S. (1973). Financial Deepening in Economic Development. Oxford University Press, New York.

Sheng, A. (1996). Bank Restructuring: Lesson from the 1980s. The World Bank. 